\title{
OFFICE PRICE INDEX LAGGING IN SINGAPORE AND HONG KONG
}

\author{
Eddie Chi Man HUI ${ }^{1}$, Ka Hung YU ${ }^{1}$ and David Kim Hin HO ${ }^{2}$ \\ 1 Department of Building and Real Estate, The Hong Kong Polytechnic University, \\ Hunghom, Kowloon, Hong Kong \\ E-mail: bscmhui@inet.polyu.edu.hk; Tel: (852) 2766 5881; Fax: (852) 27645131 \\ 2 Department of Real Estate, The National University of Singapore, Singapore
}

Received 30 November 2006; accepted 15 February 2007

\begin{abstract}
Price discovery of real estate investment has been getting lots of attentions from researchers and it is generally believed that lagging errors exist in appraisal-based returns of commercial real estate investments, in comparison to other investment instruments traded in the stock market. Due to fewer transactions in the commercial real estate market, it is reasonable to notice a difference in the handling of current market information. By introducing two study approaches along with a test case using Singapore's data, this paper explores the extent of lagging in Hong Kong's commercial (office) real estate values, in a State Space Model with Kalman filter. The findings first suggest that whether appraisalbased indices overstate or understate true values lies in the economy condition at the time. Then, commercial real estate values in Hong Kong are about three months behind the stock market property indices. Also, as indicated by the findings, data collection/selection bias may render a de-lagged index not as efficient as it is supposed to be. This paper provides a different perspective on price discovery and the process of de-lagging property values.
\end{abstract}

KEYWORDS: Price discovery; State Space Model; Kalman filter; Commercial Real Estate (Office) values

\section{INTRODUCTION}

Real Estate is an investment option not traded on the stock market. It has been illustrated in previous studies that the risk-adjusted return of real estate is higher than that of other investment goods. In other words, risk factors are priced differently on the stock market and the private commercial real estate market ( $\mathrm{Fu}, 2002)$. Therefore, investment would be less risky when real estate is included in an investment portfolio. Also, real estate investment is considered a good hedging tool against inflation (Fama and Schwert, 1977; Webb and Sirmans, 1980; Miles and McCue, 1982 \& 1984; Ibbotson and Siegel, 1984; and Brueggeman, et al., 1986).
However, there is a problem regarding the evaluation of real estate values and its return rates. Unlike the immense amount of information available on investment instruments traded on the stock market, information circulating on real estate is much less. According to Quan and Quigley (1991), costly search would be incurred by potential buyers, given the heterogeneity and fixity of real estate. Moreover, trading activities in the real estate market are decentralized and market prices are the result of negotiations between buyers and sellers. Those involved in the real estate market usually rely on very limited and partial knowledge to make decisions. This could probably lead to a gap in the bargaining power

International Journal of Strategic Property Management

ISSN 1648-715X print / ISSN 1648-9179 online (C) 2007 Vilnius Gediminas Technical University

http://www.ijspm.vgtu.lt 
between the buyer and the seller, affecting the final transaction price in the process. Moreover, insufficient market information on real estate provides difficulties for investment managers to evaluate its returns accurately, in order to judge whether real estate is a good enough instrument to be included in an investment portfolio.

Singapore and Hong Kong are selected for this study, due to two reasons. First, both of such have been perhaps two of the most prosperous cities in the world, since the 1980s. They were one-half of the famous four Little Dragons in Asia. The economic systems of Hong Kong and Singapore are similar, and both are favored by foreigners to do business with. Entrepot trade has played a crucial role in both economies. In Singapore, under intensive urban planning and rapid diversification of the Singapore economy, specifically the rapid growth of the financial and business services sectors, demand for modern office space has been robust and sustainable. It is very similar to the situation in Hong Kong, as service-oriented industries have taken over Hong Kong's economy in the 1990 s, once the secondary industries shifted their bases to Mainland China. This provides the backbone for office space demand in both cities. Secondly, both Singapore and Hong Kong were seriously wounded by the Asian Financial Crisis. As a result, the office price movements in both places were similar.

This paper will be divided into five sections. The first part is a literature review on appraisal-based returns and the problems caused by this method. Then, a literature review of the attempts to eliminate the problem of lagging in appraisal-based commercial real estate returns will be presented. The third section first introduces a single-index approach which is then applied to a test Singapore case study. Then, the model is trial-tested on a Hong Kong study, as presented in the fourth section. An alternate approach is proposed in case the first approach is not applicable within the context of Hong Kong. Further, a comparison is made with respect to how data selection bias plays a role in office price discovery and lagging. The last section concludes and summarizes the findings in this study.

\section{LITERATURE REVIEW}

\subsection{Appraisal-based returns and its problems}

It is reasonable to say that professional appraisals are generally referred to as a representation of the market value of real estate investment. The use of such appraisals aims to reduce search and information cost. Researchers, for instance, form indices on real estate values based on appraisal value, instead of transaction prices (Clayton, Geltner, and Hamilton, 2001). It goes so far as such appraisals are used to even evaluate the performance of investment managers, though such practice is generally viewed as an improper way to utilize the appraisals (Giliberto, 1988; Fisher and Geltner, 2000). Due to the impact that appraisals may have caused, one has to wonder how accurate these appraisal-based returns are, compared to its "true" return values.

Numerous studies were conducted previously to investigate the plausibility of the appraisal-based returns for real estate investments. The results are mostly negative, due to the problem of lagging (or smoothing). The reliance on previous prices (Ibbotson and Siegel, 1984), or previous appraisals (Ross and Zisler, 1987; Geltner, 1989) by appraisers in the estimation of the current market value, are the reasons contributing to the "smoothed" results. Valuations on the stock market is more updated than that on the real estate market, as real estate prices reflect the changes in market conditions slower. Fu and $\mathrm{Ng}$ (2001) find that about one half of the effect of the current market news is captured by the contemporaneous adjustment in real estate transaction prices. Therefore, it is possible that some of the impact of the outdated information is still present in the appraisal values (Fisher and Geltner, 2000). Corgel 
and deRoos (1999) state that the extraordinary risk/return relationship in appraisal-based real estate can be deciphered as a compensation for illiquidity and inefficient information. On the other hand, analyses would be erroneous without correcting the effect of smoothing (Geltner, 1991). Examples can be found on studies by Brueggeman, Chen, and Thibodeau (1984); Miles and McCue (1984); Hartzell, Hekman, and Miles (1986, 1987); Hartzell, Shulman, and Wurtzebach (1987).

Regarding inefficient information, Quan and Quigley (1991) mention that smoothing in real estate appraisals may arise from the uncertainty on the relative variability of general price, and the uncertainty on idiosyncratic transactions. The reliance on past appraisals would lead to "stale" valuations (Geltner and Goetzmann, 2000) of the current estimates, particularly when there are uncertainties regarding the information on real estate prices. But sometimes this form of appraisal still exists, even when appraisers are able to obtain new market information. It is what Clayton, Geltner and Hamilton (2001) call a behavioural component in value estimation. It is that appraisers have the tendency to "anchor" on their previous estimates. A study by Hamilton and Clayton (1999) reveal that the Canadian appraisers placed only $20 \%$ weight on current information, while the remaining $80 \%$ was based on older evidence. Also, it is found that the lag was in average 1 year between the appraisal-based values and the "true" values, while Clayton, Geltner, and Hamilton (2001) obtained similar results, with a 9-month appraisal lag. According to Fisher and Geltner (2000), lagging influences the NCREIF Property Index's (NPI) ability to provide precise indicators of market direction and behaviours, on a quarterly basis. The difference in the lagging structure of various appraisals is determined by appraisal frequency (Corgel and deRoos, 1999). The lag turns out to be smaller when the values are appraised more frequently.

As a result, there are a couple of problems when making use of the lagged appraisal re- turns data of real estate. Spurious volatility is one of them (Fisher and Geltner, 2000). Due to the prominent use of past appraisals in determining the estimates for real estate returns, naturally the change (volatility) of prices would be less than transaction-based prices. It is supported by a study from DeWit (1993), who explores that the In-house appraisals have a smaller volatility than common stock return volatility. Corgel and deRoos (1999) share similar conclusions as the appraisal-based return index understates return volatility. But they comment that the aim to inflate the return volatility may not work because changing the mean of returns would dis-magnify the effect of volatility changes on allocations. Surprisingly, Lai and Wang (1998) reach an opposite conclusion that appraisal returns are more volatile than "true" returns. But Geltner (1998) responds by stating that their definition of "true" returns is not that clear. So a different result may be obtained.

Another problem along with the appraisalbased data is seasonality. Unlike the stock market, where prices are adjusted practically in every minute, real estate prices are usually re-appraised once a year, mostly in the $4^{\text {th }}$ quarter of a fiscal year. Even though the prices are released once every 3 months, the current news does not carry too much weight on the appraisals. The lagging error appears to be smaller in the $4^{\text {th }}$ quarter when the prices are re-appraised ( $\mathrm{Fu}, 2002)$. With the presence of seasonality in appraisal-based real estate returns, Fisher and Geltner (2000) state that the National Council of Real Estate Investment Fiduciaries (NCREIF) needs to provide accurate indicators of quarterly market directions, but it is a bit short of doing so due to the lag problems. In a sense, they are implying that the NCREIF lacks credibility as a representation of the market values of commercial real estate. Fu (2002) comments that the serial auto-correlation would be artificially "inflated" and the correlation with the returns of other investment goods would be understated. 
The result of lags is a deviation of appraisalbased real estate returns from its "true" returns. A study by Geltner and Goetzmann (2000) found that there was about a $10 \%$ standard error in the appraisals for NCREIF properties. Another studies by Fisher, Miles and Webb (1999) reported that the transaction price was about $4.6 \%$ higher than the appraised value in the period of 1978-1985. Meanwhile, the percentage changed to $-4.5 \%$ in 1988-1992. Then, the transaction prices were going back up, with a $3.8 \%$ discrepancy over the appraised value. It is also observed that the absolute mean difference between appraised value and the "true" value is around 9\%-12.5\%. Such discrepancies are enough for an individual to change his investment decision. They conclude that the reliability of appraisals is affected by the stability of the market which varies by property type over time. The lagging problem looks to be more serious in commercial real estate, due to fewer transactions. Also, a number of questions are arisen. The first question is that under what circumstances does the appraised value overstate the "true" value, or vice versa? Then, is that possible to find a pattern of that?

\subsection{Ways to eliminate lags in appraisal- based returns}

As concluded by Geltner (1991), appraisalbased returns can be useful in studying the risk characteristics of commercial real estates, once the smoothing problem is corrected. Similar to that, Ross and Zisler (1991) comment that appraisal values need to be "un-smoothed" in order to recover the total returns. Therefore, in order to get rid of the lagging/smoothing problem that causes the estimates of real estate returns deviating from its "true" returns, a number of methods have been used in previous studies. One of the methods is the application of cap rate time series to real estate income time series, as seen in Firstenburg, Ross, and Zisler, 1988; Wheaton and Torto, 1989; Liu, et al., 1990. Another method is to use the indi- ces of real estate returns, grounded on hedonic models of real estate's fundamental value (see Hoag, 1980; Miles, Cole, and Guilkey, 1990). However, such methods are not able to tackle the "noise" as the returns generated from either the cap rates or hedonic models are subject to errors (Geltner, 1991).

A lagging-correction method has been utilized, called Reverse Engineering. Fisher and Geltner (2000) use this method in attempt to de-lag the NCRELF Index. However, Corgel and deRoos (1999) conclude that this method produces mixed implications for optimal portfolio allocation to real estate. In other words, it is implied that the de-lagged returns after using Reverse Engineering Method would either overstate or understate the "true" returns of real estate, thus not being able to eliminate the uncertainties incurred in such returns estimations. There are a couple of defects on Reverse Engineering (Fu, 2002). Firstly, Reverse Engineering is a reduced-form approach, which does not have the capacity to identify a dynamic lagging error structure. Then, the problem of seasonality is not addressed. Furthermore, it lacks the capacity to incorporate observable market information beyond the index itself. Fu concludes that this de-lagged index, via Reverse Engineering, is not necessarily more informative than the lagged index (the observed index).

Another method used to take care of the lagging problem in appraisal-based real estate returns is called the Repeated-Measures Regression (RMR). Geltner and Goetzmann (2000) utilize this method in attempt to de-lag the NCRELF Index. It is concluded that the RMR Index (the de-lagged index) is a better version of the NPI, which is more like an annual index than of quarterly index. They viewed the RMR Index as the NPI without "stale" valuations and artificial seasonality. Still, the downside of the RMR index is that it still lags behind the NAREIT index by about 3 years. As REITs are being traded on the stock market, the prices of REITs and the NAREIT should be the most updated values of real es- 
tate. In short, though some of the problems accompanying the lagged appraisal values are handled, it is not as close as informative as the stock market changes, granted the same current market information.

The State Space Model via Kalman Filter is introduced in Fu's (2002) study, in order to deal with the aforementioned problem. What makes the State Space Model via Kalman Filter better than the above methods? It is argued that this setting has the flexibility to allow the lagging error to be influenced by a variety of variables. That includes the latent appreciation return and seasonality. Moreover, it is, he asserts, capable of taking available market information, which can improve the forecast quality for latent appreciation return. His test on the NARELF Index shows that its return has greater volatility, improved cross-correlation with the returns of other indices affected by the same market news, and less serial auto-correlation returns, once the lag has been removed. This idea is further corroborated by Quan and Quigley (1991), saying that a full fledged Kalman filter algorithm can be employed to make the optimal updating rule more realistic.

However, most of the studies on the lagging problems of appraisal-based returns estimate focus on the data on the U.S. real estate market (i.e. NPI). There are yet studies focusing on such problems on the real estate markets in Asia. It would be worth studying the same problems in Asia, such as Hong Kong and Singapore, given their established economic structures. This study intends to bridge the knowledge gap in price discovery of commercial real estates in Asian countries/cities.

\section{STUDY APPROACHES AND SINGAPORE TEST CASE}

Using a case study on Singapore office price indices as a test case, a single-index model is constructed as the starting point of this study. The index is called the Synthetic Land Price
Index (LPI). If the LPI is workable we then use it in the subsequent analysis in the Hong Kong case. If not, a more conventional multivariable approach is then introduced exclusively for the Hong Kong study. The advantage of such comparison approach is that we may clearly distinguish which approach can work better, or more precisely, which variables can best explain the overall price adjustments of office space.

\subsection{Synthetic Office Land Price Index (LPI)}

In the construction of a synthetic office land price index within the context of Singapore, the required data set is obtained from the URA Office Rental and Capital Value (CV) Indices and the JLL REIS-Asia real estate market indicators or variables. With the construction of this office land price index, it serves as a measure of the rate of $\mathrm{CV}$ appreciation of vacant office land in Singapore. The index can then be compared with the price indices of built up office assets that are maintained by URA, in order to determine to what extent would movement in the CV of office land explain the CV movement of built-up office assets. Essentially, the LPI is the difference between the supply price of capital (proxied by best lending rate) and the current rental return of an office asset (proxied by yield rate/capitalization rate). Calculations of the Synthetic Office Price Index are demonstrated in Table 1.

\subsection{State Space Model \& Kalman Filter}

A State Space Model, with Kalman Filter, is deployed to find out how the observed Office Price Index deviates from its supposed "true" value, due to the lag structure in the appraisal values. Kalman Filter is a recursive algorithm for sequentially updating the 1-stepahead estimate of the state mean and variance, once there is new information available (EViews Manual, p. 561). According to Kalman (1963), the signal value is equal to the mes- 
Table 1. Derived Synthetic Singapore Office Land Price Index (Base Year = 1990)

\begin{tabular}{|c|c|c|c|c|c|c|c|c|c|c|}
\hline Year & $\begin{array}{l}\text { URA } \\
\text { Office } \\
\text { Rental } \\
\text { Index }\end{array}$ & $\begin{array}{l}\text { URA } \\
\text { Office } \\
\text { CV } \\
\text { Index }\end{array}$ & $\begin{array}{l}\text { JLL } \\
\text { Office } \\
\text { Rent }\end{array}$ & $\begin{array}{l}\text { JLL } \\
\text { Rental } \\
\text { Index }\end{array}$ & $\begin{array}{l}\text { JLL Office } \\
\mathrm{CV}\end{array}$ & $\begin{array}{l}\text { JLL } \\
\text { Office } \\
\text { CV } \\
\text { Index }\end{array}$ & $\begin{array}{l}\text { Yield } \\
(\%)\end{array}$ & $\begin{array}{l}\text { PLR } \\
(\%)\end{array}$ & $\begin{array}{l}\text { Land } \\
\text { Price } \\
\text { Inflation } \\
\text { Rate }(\%)\end{array}$ & LPI \\
\hline 1990 & 128.2 & 87 & 1032.00 & 347.47 & 17222.00 & 103.97 & 5.91 & 7.73 & -1.82 & 100.00 \\
\hline 1991 & 119.4 & 87.6 & 902.00 & 303.70 & 16884.00 & 100.72 & 5.24 & 7.10 & -1.86 & 98.14 \\
\hline 1992 & 99 & 75 & 602.25 & 202.78 & 14393.67 & 86.89 & 3.61 & 5.55 & -1.94 & 96.23 \\
\hline 1993 & 86.2 & 84.7 & 423.16 & 142.48 & 14400.28 & 86.93 & 2.94 & 5.34 & -2.40 & 93.92 \\
\hline 1994 & 96.6 & 127.3 & 511.674 & 172.28 & 17444.52 & 105.31 & 3.55 & 6.49 & -2.94 & 91.17 \\
\hline 1995 & 126.5 & 157.7 & 643.12 & 216.54 & 17290.56 & 104.38 & 3.69 & 6.28 & -2.57 & 88.82 \\
\hline 1996 & 126.5 & 155.1 & 745.46 & 251.00 & 20322.66 & 122.68 & 4.31 & 6.26 & -1.95 & 87.09 \\
\hline 1997 & 119.6 & 139 & 571.35 & 192.37 & 17516.50 & 105.74 & 2.81 & 6.96 & -4.15 & 83.48 \\
\hline 1998 & 100 & 100 & 501.78 & 168.95 & 11994.41 & 72.41 & 2.86 & 5.90 & -3.04 & 80.94 \\
\hline 1999 & 90.5 & 99 & 395.70 & 133.23 & 9919.43 & 59.88 & 3.30 & 5.80 & -2.50 & 78.92 \\
\hline 2000 & 102.2 & 129.3 & 674.39 & 227.07 & 15046.36 & 90.83 & 6.80 & 5.80 & 1.00 & 79.71 \\
\hline 2001 & 94.2 & 100.1 & 761.09 & 256.26 & 13484.65 & 81.40 & 5.06 & 5.35 & -0.29 & 79.47 \\
\hline 2002 & 82.9 & 83.4 & 530.92 & 178.76 & 10903.34 & 65.82 & 3.94 & 5.35 & -1.41 & 78.35 \\
\hline
\end{tabular}

sage plus noise (random error term). If the error term is under Gaussian distribution, the Kalman filter provides an estimate of the state that is best available, which is in terms of a minimum mean estimator (Wells, 1996).

\subsection{The Singapore test study}

Firstly, the variables used in the model have to be defined. The state space model, is built around two major variables, which are the URA Office Capital Index (UOCV) and the Synthetic Office Land Price Index (LPI), as in,

$\mathrm{Y}_{\mathrm{t}} \equiv$ URA Office Capital Value Index at time period $t$

$\equiv \mathrm{UOCV}$, (dependent variable)

and $\mathrm{X}_{\mathrm{t}} \equiv$ Synthetic Office Land Price Index at time period $t$

$\equiv$ LPI (independent variable)

Then, the following observation equation and a state equation can be expressed.

Observation equation:

$$
U O C V_{(t)}=C_{1}+\beta_{1} \times L P I_{(t)}+\beta_{2}
$$

State equation:

$$
\beta_{1(t)}=\beta_{1(t-1)}+v_{(t)}
$$

$$
\beta_{2(t)}=C_{3} \times \beta_{2(t-1)}+\left\{\operatorname{Var}=\operatorname{Exp}\left(C_{2}\right)\right\}
$$

where: $\mathrm{C}_{1}, \mathrm{C}_{2}, \mathrm{C}_{3} \equiv$ fixed parameters; $\beta_{2} \equiv$ disturbance term; $\mathrm{v}_{(\mathrm{t})} \equiv$ disturbance term at time $t$.

The slope coefficient follows an unrestricted first-order autoregressive generation process, or a lagging structure of 1 period (1 year).

The Singapore study covers the prime office sector in Singapore's Central Business District (CBD), utilizing the Jones Lang LaSalle Real Estate Intelligence Service-Asia (JLL REIS-Asia) dataset. The dataset comprises the prime office rents and CVs for thirty Grade A buildings in the three main CBD areas - the Raffles Place, Shenton Way and the Marina Centre CBD areas. The dataset period of some thirteen years spans from 1990 to 2002. This paper also utilizes the URA office rental and CV indices, the most widely used indicators of real estate prices in Singapore, and are obtained from the URA Real Estate Information System (REALIS) database. 


\subsection{Empirical findings of Singapore test study}

With the assistance of the EViews software, results obtained from the state space model and Kalman filter for the Singapore study is illustrated in Table 2, and Figure 1 shows the deviation of the de-lagged UOCV from the observed UOCV.

It can be observed that there is a lagging problem of about 1 year for the UOCV in Sin- gapore. The observed UOCV is higher than the de-lagged UOCV most of the time. The opposite happened right around the time when the Asian Financial Crisis took place, and the most recent two years of the studied period. In a sense, the observed (lagged) UOCV tends to overstate the "true" value, except when the economy is going down.

Table 2. Results for the OPI in Singapore

\begin{tabular}{lllll}
\hline & Coefficient & Std. Error & z-Statistic & Prob. \\
\hline $\mathrm{C}_{(1)}$ & 72.03209 & 382.8607 & 0.188142 & 0.8508 \\
$\mathrm{C}_{(2)}$ & 6.232012 & 0.634240 & 9.825947 & 0.0000 \\
$\mathrm{C}_{(3)}$ & 0.976748 & 0.001615 & 604.7464 & 0.0000 \\
\hline & Final State & Root MSE & z-Statistic & Prob. \\
\hline$\beta_{1}$ & 2.387453 & 6.078636 & 0.392761 & 0.6945 \\
$\beta_{2}$ & -171.6039 & 465.7338 & -0.368459 & 0.7125 \\
\hline
\end{tabular}

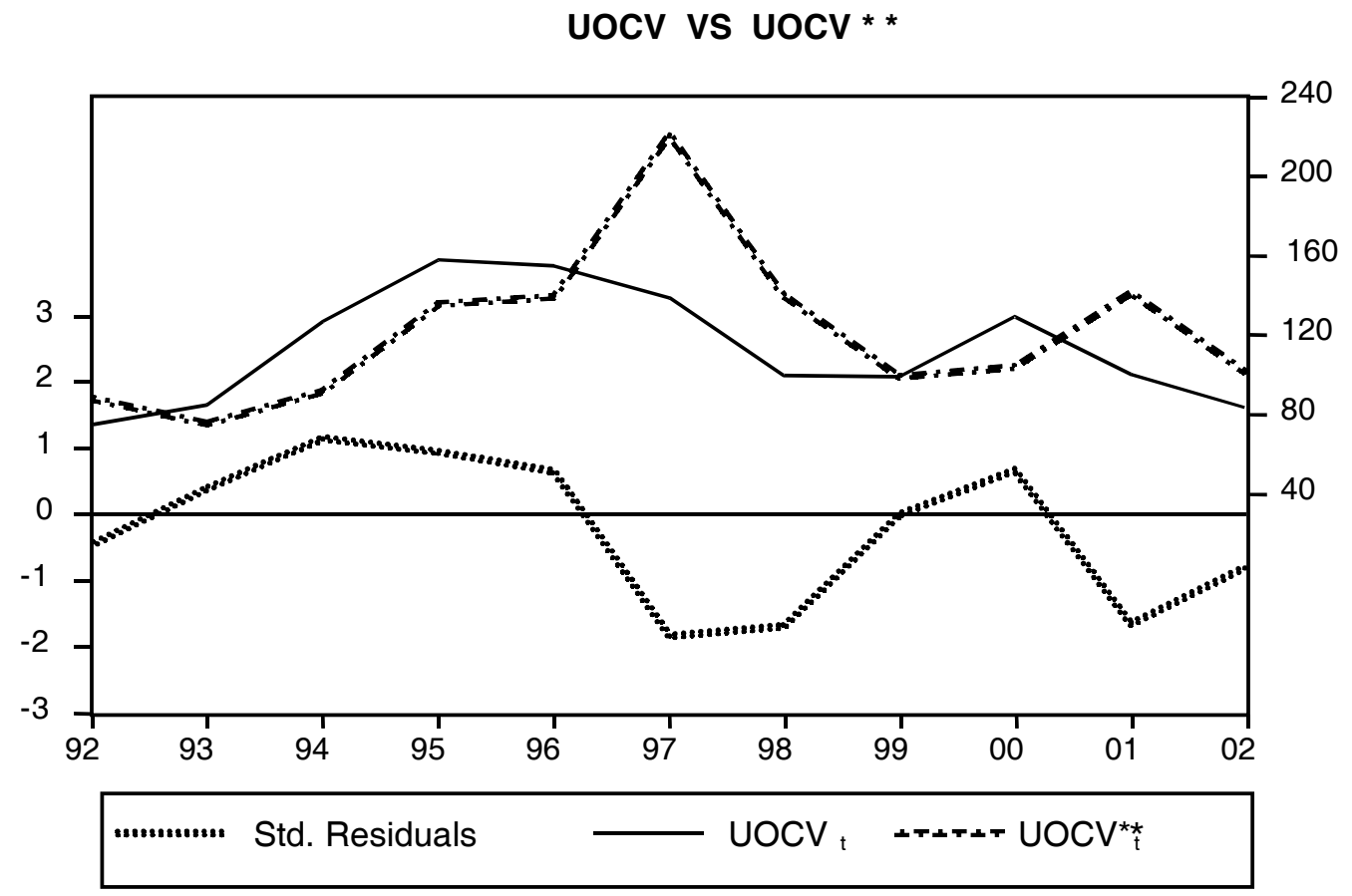

Figure 1. The Lagged $U O C V_{t}$ against the De-Lagged $U_{O C V}$ ** 


\section{THE HONG KONG STUDY}

The Hong Kong study focuses on the price discovery of Class A office only. Yearly data from 1990 to 2002 are gathered from the Census \& Statistics Department, Rating and Valuation Department (RVD), and HSBC (best lending rate).

The Office Price Index (OPI), conducted by RVD, is primarily transaction-based, buit the information for controlling quality constant is partially valuation-based. Index construction is based of Actual price data (price per saleable floor area) in the Agreement for Sale and Purchase (ASP) of transacted properties in each sub-sector (by property types) (Chau et al., 2005). In short, it is possible for lags to exist in the valuation process of OPI.

However, a trial test on Hong Kong's OPI indicates that LPI is somehow not a significant indicator in explaining price index movements (Table 3). Moreover, it is believed that negative OPI figures could be generated, given the small constant term $\left(\mathrm{C}_{1}\right)$ and a large negative noise term $\left(\beta_{2}\right)$, which renders some very questionable outcomes. Due to the use of yearly data, one may question whether it is the data itself, or the model, that leads to this problem.

As a result, we move to the second stage of the methodology as a multi-variable approach is deployed for the Hong Kong case study, which involves some other market fundamentals as well in capturing Hong Kong's office price adjustments. Under the same background methodology of a State Space Model, the observation equation is as follows:
Observation equation:

$$
\begin{aligned}
& \text { OPI }_{(t)}=C_{1}+\beta_{1} \times \text { cpicomposite }_{(t)}+ \\
& \beta_{2} \times \text { gdpgrowth }_{(t)}+\beta_{3} \times \text { yieldrate }_{(t)}+ \\
& \beta_{4} \times \text { bestlendingrate }_{(t)}+ \\
& \beta_{5} \times \text { unemployment }_{(t)}+\beta_{6}
\end{aligned}
$$

State equations:

$$
\begin{aligned}
& \beta_{1(t)}=\beta_{1(t-1)}+v_{(t)} \\
& \beta_{2(t)}=\beta_{2(t-1)}+u_{(t)} \\
& \beta_{3(t)}=\beta_{3(t-1)}+s_{(t)} \\
& \beta_{4(t)}=\beta_{4(t-1)}+v_{(t)} \\
& \beta_{5(t)}=\beta_{5(t-1)}+v_{(t)} \\
& \beta_{6(t)}=C_{3} \times \beta_{6(t-1)}+\left\{\operatorname{Var}=\operatorname{Exp}\left(C_{2}\right)\right\}
\end{aligned}
$$

where: $\mathrm{C}_{1}, \mathrm{C}_{2}$ and $\mathrm{C}_{3} \equiv \mathrm{a}$ fixed parameter/ constant term; $\mathrm{m}_{(\mathrm{t})}, \mathrm{n}_{(\mathrm{t})}, \mathrm{v}_{(\mathrm{t})}, \mathrm{u}_{(\mathrm{t})}$ and $\mathrm{s}_{(\mathrm{t})} \equiv$ disturbance terms at time $t$.

The inclusion of the GDP growth rate is quite easy to fathom. The movement of GDP is usually viewed as the general performance of an economy. It is reasonable to say that the higher the GDP growth rate, the better perception of an economy. Hong Kong's becoming of one of

Table 3. Trial test results of Hong Kong's OPI under the one-index model

\begin{tabular}{lllll}
\hline & Coefficient & Std. Error & z-Statistic & Prob. \\
\hline $\mathrm{C}_{(1)}$ & -3.14351711023 & 450.609753403 & -0.00697614085467 & 0.994433890065 \\
$\mathrm{C}_{(2)}$ & 7.21131956223 & 0.515930453956 & 13.9773093581 & $2.14443115793 \mathrm{e}-44$ \\
$\mathrm{C}_{(3)}$ & 0.975927193715 & 0.00656068136515 & 148.753938714 & 0 \\
\hline & Final State & Root MSE & z-Statistic & Prob. \\
\hline$\beta_{1}$ & 4.43274126356 & 7.0141919865 & 0.631967484221 & 0.527408124578 \\
$\beta_{2}$ & -263.574375912 & 532.608606567 & -0.494874421222 & 0.620688767359 \\
\hline
\end{tabular}


the four Little Dragons in Asia was the result of comparatively high GDP growth at the time. Under such circumstances, investors, local or foreign, would be more willing to spend money on a variety of businesses which not only offer lots of job opportunities, but also the demand for office spaces. Then, there would have a positive effect on commercial real estate prices and rents. That would cause a certain degree of impact to the yield rates, thus the appraisal-based price indexes. Moreover, this is the same piece of information that the stock market would digest, only more efficiently and faster. Such discrepancy regarding the handling of the same information is where the controversy concerning appraisal-based index commences.

As far as the CPI growth rate is concerned, one of the basic functions of real estate, as mentioned before, is to be used as a hedge against inflation. This insinuates that a higher inflation rate would likely lead to a higher demand for real estate, either commercial or residential. Also, the effect of inflation may initiatively give us an idea of how well real estate performs, in terms of the yield rate. However, a high yield rate does not necessarily make a real estate investment attractive, as the best lending rate could escalate in inflationary periods, which increases the cost of capital. The less risky savings rate would soar as well, providing a good alternative to real estate investment.
Unemployment situation in a sense gives decision-makers a closer look at the economic situation in a place, aside from GDP movements. An improving GDP may reflect a positive perspective about an economy, but such improvement may not benefit the people at all. Unemployment insinuates the loss of a stable source of income for individuals, which would make them more cautious on the consumption of goods and services. This would impede the economic development in years to come, thus affecting the expected profit level that businesses will obtain. This would influence the demand for office space, thus determining its price movement.

\subsection{Empirical Findings of Hong Kong case study}

Similar to the trial test under the one-index LPI model, something interesting can be found. The results are shown in Table 4.

According to $\mathrm{Fu}$ (2002), if the de-lagged price index is indeed more efficient than the original index, greater volatility in the returns, improved cross-correlation with the returns of other indices, and a smaller serial-correlation in returns should be observed. Therefore, it is impossible to conclude anything before comparing the above two indexes with the more market-efficient indices in the stock market.

Table 4. Results obtained for Hong Kong study, using the state space model with Kalman filter

\begin{tabular}{lllll}
\hline & Coefficient & Std. Error & z-Statistic & Prob. \\
\hline $\mathrm{C}_{(1)}$ & 403.8533 & 68.59492 & 5.887510 & 0.0000 \\
$\mathrm{C}_{(2)}$ & 5.567675 & 0.433702 & 12.83757 & 0.0000 \\
$\mathrm{C}_{(3)}$ & 0.288099 & 0.010166 & 28.33888 & 0.0000 \\
\hline & Final State & Root MSE & z-Statistic & Prob. \\
\hline$\beta_{1}$ & 2.062854 & 2.283049 & 0.903552 & 0.3662 \\
$\beta_{2}$ & -1.278292 & 1.377705 & -0.927842 & 0.3535 \\
$\beta_{3}$ & -38.36837 & 6.055927 & -6.335673 & 0.0000 \\
$\beta_{4}$ & -1.114006 & 2.975982 & -0.374332 & 0.7082 \\
$\beta_{5}$ & -8.230984 & 6.953270 & -1.183757 & 0.2365 \\
$\beta_{6}$ & 3.133870 & 16.76549 & 0.186924 & 0.8517 \\
\hline
\end{tabular}


In this case, we use the Hang Seng Property Index in the same period, to find out the crosscorrelation between stock market adjustments and office price adjustments. Actually, financial instruments like Real Estate Investment Trust (REIT) is a closer alternative for real estates traded in the stock market. However, there has been no issuance of REIT in Hong Kong until mid-2003. As a result, it is replaced by the Hang Seng Property Index (HSPI). It is viewed that the HSPI is more updated and more efficient, in terms of handling current market information, than the office price index. Data of the HSPI is collected from the DataStream Database, and yearly averages of the HSPI are calculated for comparison. The results are shown in Table 5.

For some reason, the de-lagged index actually is negatively correlated with the Hang Seng Property Index. Worse, negative predicted values are generated, which is nonsensical as the dependent variable in this model is in the form of an index, which can only be positive. This shows that the de-lagged OPI informs us even less about the market when more market information is put into the model, or we are not able to conclude that there is any lagging problem in Hong Kong's OPI during 1990-2002. However, what is the reason behind such discrepancies from the de-lagged OPI? Does it mean there are really no lagging problems on Hong Kong's OPI, or is it something else that induces this unique outcome?

\subsection{Findings on the lagging issues of OPI, using quarterly data}

Because of such abnormities, we look for an alternative to find out the possible reason behind such discrepancies. This time, quarterly data is used in order to explore the possible lagging problem in the office price index in Hong Kong in the same period of 19902002. An assumption is needed before further discussions, based on the unique situations involving yearly data, which is that the possible lag term in Hong Kong's OPI is less than a year. There is an advantage of using quarterly data over yearly data, which is the ability to locate a closer estimate of the duration of lagging phenomenon in Hong Kong's office price index. Usually, two options can be found with yearly data, either no lag or a first-order lag ( 1 year). But by using quarterly data, five options can be looked at, which are no lag, 3-month, 6-month, 9-month, and 12month lag in the OPI. Table 6 illustrates the results generated by the state space model with Kalman filter, and Figure 2 shows the movement of the predicted OPI throughout the study period.

In Figure 2, it can be seen that there is no negative values found in the de-lagged OPI in the period 1990-2002, when quarterly data is used. Though the deviations between the observed OPI and the de-lagged OPI are not that noticeable, it can be discerned that the observed OPI tend to overstate the "true" value when prices are going up, and vice versa. This is in line with the Singapore study over the same period of time. It is reasonable to say that the economic condition in a particular time frame determines the trend of appraisal-based price index values. When different periods of time are studied, it may induce various outcomes. In other words, it is uncertain that whether an appraisal-based values/returns would either overstate or understate its "true"

Table 5. Pearson Correlation between Hang Seng Property Index (Yearly Average) and observed/de-lagged OPI

\begin{tabular}{ll}
\hline Variables & Pearson Correlations with Hang Seng Property Index \\
\hline Observed OPI & 0.530 \\
De-lagged OPI & -0.420 \\
\hline
\end{tabular}


Table 6. Results of Hong Kong study (quarterly data)

\begin{tabular}{lllll}
\hline & Coefficient & Std. Error & z-Statistic & Prob. \\
\hline $\mathrm{C}_{(1)}$ & 963.3491 & 11714.04 & 0.082239 & 0.9345 \\
$\mathrm{C}_{(2)}$ & 4.376352 & 0.160423 & 27.28001 & 0.0000 \\
$\mathrm{C}_{(3)}$ & 1.001496 & 0.020284 & 49.37410 & 0.0000 \\
\hline & Final State & Root MSE & & Prob. \\
\hline$\beta_{1}$ & 1.089054 & 0.879948 & & 0.2159 \\
$\beta_{2}$ & -0.313584 & 0.887129 & & 0.7237 \\
$\beta_{3}$ & -13.78344 & 2.273493 & 0.0000 \\
$\beta_{4}$ & -2.351217 & 2.625139 & 0.3704 \\
$\beta_{5}$ & -9.535058 & 2.713477 & & 0.0004 \\
$\beta_{6}$ & -821.4843 & 86.70502 & & 0.0000 \\
\hline
\end{tabular}

Note: the result is generated under a first-order autocorrelation process, which puts a 3-month lagging problem into consideration.

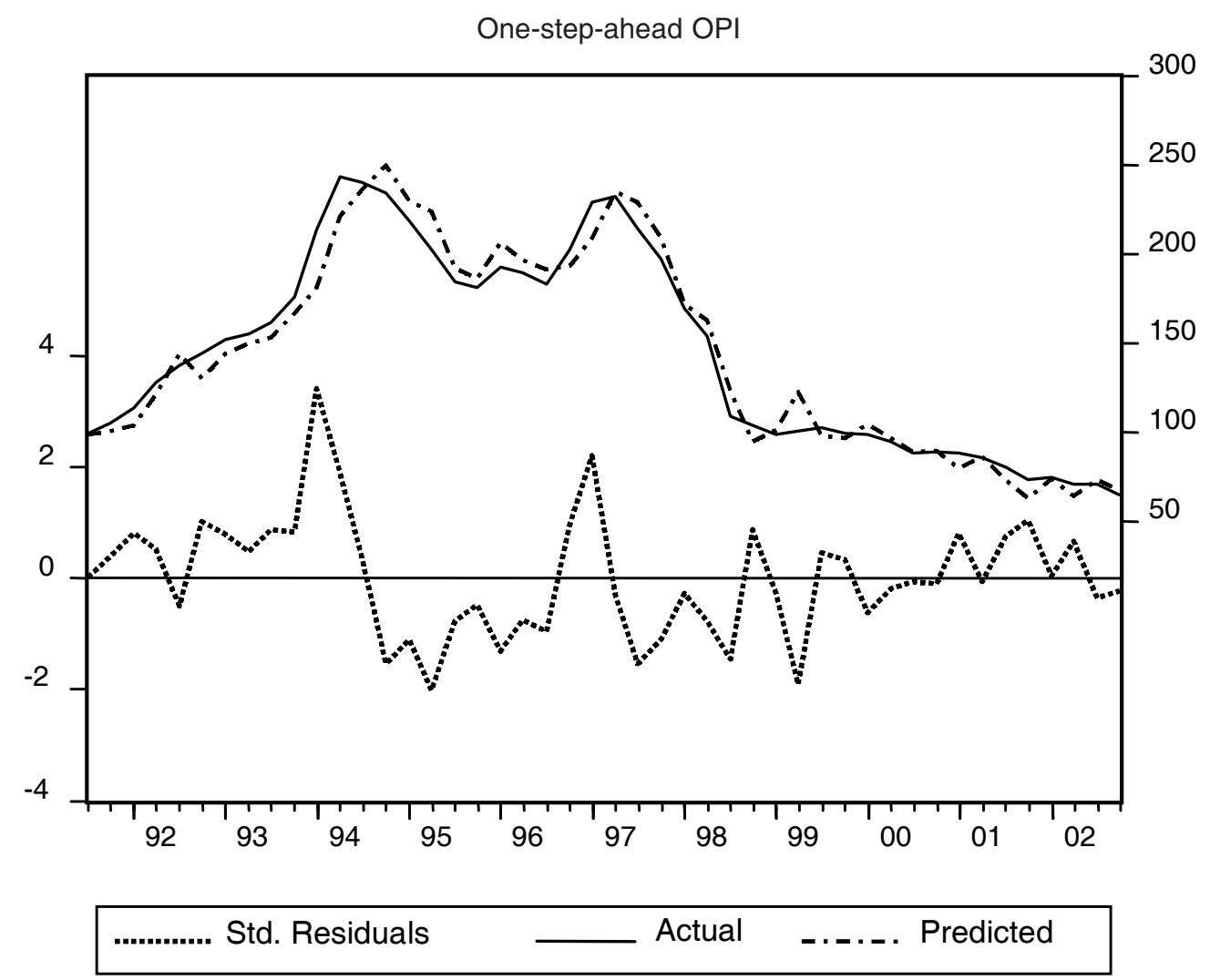

Figure 2. Actual (Observed) OPI vs. Predicted (De-lagged) OPI 
values. The main deciding item of such is the economic trend at the time.

Furthermore, to see if the de-lagged OPI is more informational than the observed OPI, correlation tests are carried out, comparing the de-lagged values (3-month, 6-month, 9-month, and 12-month lagging patterns) to the Hang Seng Property Index. The quarterly average of such index is used for comparison, and the results are shown in Table 7.

It can be observed that with the exception of $\mathrm{OPI}(2)$, which is under a 6-month lagging pattern, the remaining values have similar Pearson correlations with the HSPI. The delagged OPI(1) has a higher correlation with the HSPI, at 0.537 , than that of the observed OPI, at 0.494 . It can be concluded that the OPI in Hong Kong has a 3-month lagging problem. It should be noted that the reason for the relatively low correlation values with HSPI (about one-half) is that the Hang Seng Property Index essentially represents companies specializing in both residential and commercial real estates. Meanwhile, this study only focuses on the price discovery of commercial real estate, due to its relatively fewer transactions.

As expected, the lag term is within 0-12 months. However, such lag term can only be obtained when quarterly data is utilized. The point is that, it is possible that the impact, or the lag term of appraisal-based values/returns could be over-estimated during price discovery. In the Hong Kong study, it is reasonable to say that there does not seem to have a lagging problem in the OPI, as its correlation with HSPI is higher than the de-lagged OPI. It looks to be the case if the study ends there, but instead, it is discerned in the second test that lagging problem does exist in the observed OPI, only to be much less than a year. The lagging problem may be not as serious as some researches tend to inform us. In other words, part of the lagging may be induced by not only the true lagging phenomenon (insufficient transactions), but also the bias in data collection. The intention of locating lagging problems is to provide a more informational and efficient indicator of the values/returns of commercial real estate, but bias in data collection may lead to even more misleading results obtained for references.

\section{CONCLUSION}

The phenomenon of lagging in commercial real estate price discovery has been investigated. A study of the price dynamics of Hong Kong's office space, from 1990-2002, suggests that appraisal-based office price indices tend to overstate the "true" values when the economy is performing well, otherwise when the economy is encountering a downturn. It is different from the previous studies which provide conflicting accounts of whether appraisalbased values/returns overstate or understate its "true" values. It appears that the determinant for the above question lies in the economic conditions of the study period. Also, comparing the two study approaches, the inclusion of more economic variables (multi-variable approach) in the Hong Kong study enhances the efficiency of the estimated de-lagged index, compared to a single-index approach (LPI).

Table 7. Pearson Correlation between Hang Seng Property Index and (Observed/De-lagged) OPI

\begin{tabular}{ll}
\hline Variable & Correlations with Average Hang Seng Property Index \\
\hline Observed OPI & $0.494^{* *}$ \\
De-lagged OPI(1) (3 months) & $0.537 * *$ \\
De-lagged OPI(2) (6 months) & 0.232 \\
De-lagged OPI(3) (9 months) & $0.496 * *$ \\
De-lagged OPI(4) (12 months) & $0.498^{* *}$ \\
\hline
\end{tabular}

** Correlation is significant at the 0.01 level (2-tailed). 
Then, this study finds that researches focusing on discovering lagging problems of appraisal-based values may not be as accurate as they are supposed to be. The reason is that bias in the data collection (or selection) process may over-estimate the impact/length of lagging problems. The Hong Kong study illustrates that there is a lagging problem of around 3 months, which in a sense cannot be detected using yearly data.

The process of de-lagging aims at providing a more efficient indicator for individuals' references regarding the leasing/purchasing of commercial real estates. However, with data collection bias put into consideration, such process may not generate a more satisfactory solution of the problem of lagging than the observed values. This paper has given some different insights on the process known as delagging of appraisal-based values/returns of commercial real estates. Much like the contemporary studies on price discovery, it is hardly convincing to say that the phenomenon of lagging does not exist at all. The concern is towards the extent of price index lagging, which can be varied by means of data selection and bias. Appraisal-based price indices or returns are lagged, but it is shown that those values may not be as "non-trustworthy" as we are led to believe.

\section{Acknowledgements}

This work was supported by the grants from the Hong Kong Polytechnic University (Project Codes: A-PG39 and Z02Z).

\section{REFERENCES}

Brueggeman, W. B., Chen, A. H. and Thibodeau, T. (1984) Real Estate Investment Funds: Performance and Portfolio Considerations, AREUEA Journal, 12(3), p. 333-354.

Clayton, J., Geltner, D. and Hamilton, S. W. (2001) Smoothing in Commercial Property Valuations: Evidence from Individual Appraisals. Real Estate Economics, 29(3), p. 337-360.
Corgel, J. B. and deRoos, J. A. (1999) Recovery of Real Estate Returns for Portfolio Allocation. Journal of Real Estate Finance and Economics, 18(3), p. 279-296.

DeWit, D. P. M. (1993) Smoothing Bias in In-House Appraisal-Based Returns of Open-End Real Estate Funds. Journal of Real Estate Research, 8(2), p. 157-170.

Fama, E. F. and Schwert, G. V. (1977) Asset Returns and Inflation. Journal of Financial Economics, 5(2), p. 115-146.

Firstenberg, P., Ross, S. and Zisler, R. (1988) Real Estate: The Whole Story. Journal of Portfolio Management, 14(1), p. 22-34.

Fisher, J. D. and Geltner, D. (2000) De-Lagging the NCRELF Index: Transaction Prices and Reverse-Engineering. Real Estate Finance, 17(1), p. 7-22.

Fisher, J. D., Miles, M. E. and Webb, R. B. (1999) How Reliable are Commercial Appraisals? Another Look. Real Estate Finance, 16(3), p. 9-15.

$\mathrm{Fu}, \mathrm{Y}$. (2002) Estimating Lagging Error in Real Estate Price Indices. Real Estate Economics, 31(1), p. 75-98.

Fu, Y. and Ng, L. K. (2001) Market Efficiency and Return Statistics: Evidence from Real Estate and Stock Market Using a Present-Value Approach. Real Estate Economics, 29(2), p. 227-250.

Geltner, D. M. (1989) Estimating Real Estate's Systematic Risk from Aggregate Level AppraisalBased Returns. AREUEA Journal, 17(4), p. $463-481$.

Geltner, D. M. (1991) Smoothing in Appraisal-Based Returns. Journal of Real Estate Finance and Economics, 4(3), p. 327-345.

Geltner, D. M. (1998) Appraisal Smoothing: The Other Side of the Story-A comment, Financial Economic Network, www.ssrn.com, Working Paper, Department of Finance, University of Cincinnati.

Geltner, D. and Goetzmann, W. (2000) Two Decades of Commercial Property Returns: A RepeatedMeasures Regression-Based Version of the NCRELF Index. Journal of Real Estate Finance and Economics, 21(1), p. 5-21.

Giliberto, S. M. (1988) A Note on the Use of Appraisal Data in Indexes of Performance Measurement. AREUEA Journal, 16(1), p. 77-83.

Hamilton, S. and Clayton, J. (1999) Smoothing in Commercial Property Valuations: Evidence 
from the Trenches. Real Estate Finance, 16(3), p. $16-26$.

Hartzell, D. J., Hekman, J. S. and Miles, M. E. (1986) Diversification Categories in Investment Real Estate. AREUEA Journal, 14 (2), p. 230-254.

Hartzell, D. J, Hekman, J. S. and Miles, M. E. (1987) Real Estate Returns and Inflation. AREUEA Journal, 15(1), p. 617-637.

Hartzell, D. J., Shulman, D. and Wurtzebach, C. (1987) Refining the Analysis of Regional Diversifications for Income-Producing Real Estate. Journal of Real Estate Research, 2(2), p. 85-96.

Ho, D. (2004) Price Discovery Lagging Error of Office Capital Values and Synthetic Office Land Prices Estimated under the Kalman Filter and Auto Regression, Working Paper, Department of Real Estate, School of Design and Environment, National University of Singapore.

Hoag, J. W. (1980) Toward Indices of Real Estate Value and Return. Journal of Finance, 35(2), p. $569-580$.

Ibbotson, R. G. and Siegal, L. B. (1984) Real Estate Returns: A Comparison with Other Investments. AREUEA Journal, 12(3), p. 219-242.

Lai, T. and Wang, K. (1998) Appraisal Smoothing: The Other Side of the Story. Real Estate Economics, 26(3), p. 511-535.

Liu, C. H., Hartzell, D. J., Grissom, T. V. and Greig, W. (1990) The Composition of the Market Portfolio and Real Estate Investment Performance. AREUEA Journal, 18(1), p. 49-75.
Miles, M. and McCue, T. (1984) Commercial Real Estate Returns. AREUEA Journal, 12(3) p. 355-377.

Miles, M. E. and McCue, T. E. (1982) Historic Returns and Institutional Real Estate Portfolios. AREUEA Journal, 10(2), p. 184-199.

Miles, M. E., Cole, R. A. and Guilkey, D. (1990) A Different Look at Commercial Real Estate Returns. AREUEA Journal, 18(4), p. 403-431.

Quan, D. C. and Quigley, J. M. (1991) Price Formation and the Appraisal Function in Real Estate Markets. Journal of Real Estate Finance and Economics, 4(2), p. 127-146.

Ross, S. and Zisler, R. (1987) Managing Real Estate Portfolios, Part 3: A Closer Look at Equity Real Estate Risk, Goldman Sachs Real Estate Research (November 1987).

Webb, J. and Sirmans, C. F. (1980) Yields and Risk Measures for Real Estate, 1966-1977. Journal of Portfolio Management, 7(1), p. 14-19.

Wells, C. (1996) The Kalman Filter in Finance, Kluwer Academic Publishers, Dordrecht, The Netherlands.

Wheaton, W. C. and Torto, R. G. (1989) Income and Appraised Values: A Reexamination of the FRC Returns Data. AREUEA Journal, 17(4), p. $439-449$.

Other sources

Rating \& Valuation Department http:// www.info.gov.hk/rvd

Census \& Statistics Department http:// www.info.gov.hk/censtatd

HSBC http://www.hsbc.com.hk

\section{SANTRAUKA}

\section{BIURŲ KAINŲ INDEKSO ATSILIKIMAS SINGAPŪRE IR HONKONGE}

\section{Eddie Chi Man HUI, Ka Hung YU, David Kim Hin HO}

Investicijų i nekilnojamaji turtą kainos mokslininkus itin domina. Dažnai manoma, kad, palyginti su kitais akcijų biržoje siūlomais investiciniais instrumentais, investicijų i k komercini nekilnojamaji turtą grąža vertinama klaidingai dèl atsilikimo. Kadangi komercinio nekilnojamojo turto rinkoje sandorių sudaroma mažiau, verta pabréžti, kaip skirtingai tvarkoma aktuali rinkos informacija. Pristatant du tyrimo būdus kartu su atvejo tyrimu pagal Singapūro duomenis, šiame darbe, remiantis būsenu erdvès modeliu ir naudojant Kalmano filtrą, nagrinejjamas Honkongo komercinio nekilnojamojo turto (biurų) verčių atsilikimas. Išvados pirmiausia rodo, kad tai, ar vertinimu pagrịsti indeksai padidina ar sumažina realias vertes, priklauso nuo esamų ekonominių sąlygų. Be to, komercinio nekilnojamojo turto vertès Honkonge nuo akcijų rinkoje naudojamų nuosavybės indeksų atsilieka apie tris mėnesius. Išvados rodo ir tai, kad dèl šališko duomenų rinkimo (atrankos), neatsiliekantis indeksas gali būti ne toks efektyvus, kaip turètų būti. Šiame darbe pateikiamas kitas kainų nustatymo būdas ir aprašomas nuosavybès vertès atsilikimo panaikinimo procesas. 